\title{
Antimicrobial activity of autoclaved and non autoclaved copaiba oil on Listeria monocytogenes
}

\author{
Atividade antimicrobiana de óleo de copaíba autoclavado e não autoclavado sobre \\ Listeria monocytogenes
}

\section{Fábio Alessandro Pieri' ${ }^{I}$ Raphaela Mansur José ${ }^{I}$ Newton Nascentes Galvão ${ }^{I}$ Luis Augusto Nero ${ }^{\mathrm{I}}$ Maria Aparecida Scatamburlo Moreira ${ }^{\mathrm{I} *}$}

\begin{abstract}
The aim of this study was to evaluate the antimicrobial effect of different copaiba oil concentrations against the growth of Listeria monocytogenes, and analyze differences in inhibition of microorganisms with autoclaved and non autoclaved oil. This study provided an agar diffusion test with six isolates of bacteria and six different concentrations of autoclaved or non autoclaved copaiba oil and a negative control. The results showed sensitivity of five $\mathbf{L}$. monocytogenes isolates related to the $10 \%$ autoclaved solution of copaiba oil. Four strains also showed sensitivity to the 5\% autoclaved solution and one to $2.5 \%$ autoclaved solution. The $10 \%$ non autoclaved oil solution showed growth inhibition only for two strains. These results had pointed the $10 \%$ autoclaved solution of copaiba oil with higher inhibition as all other solutions and concentrations tested $(P<0.05)$. For the other concentrations of both solutions, the 5 and $2.5 \%$ autoclaved and $10 \%$ non autoclaved solutions had presented statistically equal. All other concentrations of both copaiba solutions and the negative control did not presented any bacteria inhibition. In conclusion, the results of this study suggest that the autoclaved copaiba oil may be a potential new agent source for infection control or for food preservation, inhibiting the growth of food-borne bacteria such as L. monocytogenes.
\end{abstract}

Key words: phytotherapics, Copaifera, antimicrobial drugs, Listeria monocytogenes.

\section{RESUMO}

Os objetivos deste estudo foram avaliar o efeito antimicrobiano de diferentes concentrações de óleo de copaíba contra o crescimento de Listeria monocytogenes e analisar as diferenças na inibição do microorganismo com soluções do óleo autoclavadas e não autoclavadas. Para tanto, foi realizado um teste de difusão em ágar, com seis isolados do microrganismo originários de produtos cárneos, seis concentrações de ambas as soluções e um controle negativo. Os resultados mostraram sensibilidade de cinco cepas de $\boldsymbol{L}$. monocytogenes em relação à solução $10 \%$ de óleo de copaíba autoclavada. Quatro isolados também apresentaram sensibilidade para a solução de 5\% autoclavada e apenas um foi sensível à solução de $2,5 \%$ autoclavada. A solução $10 \%$ não autoclavada apresentou inibição do crescimento de apenas dois isolados. Esses resultados apontaram a solução autoclavada de $10 \%$ do óleo de copaíba com maior inibição em relação a todas as outras soluções e concentrações testadas $(P<0,05)$. As soluções 5 e 2,5\% autoclavadas e a solução $10 \%$ não autoclavada apresentaram-se estatisticamente iguais. Todas as outras concentrações das soluções de copaíba e o controle negativo não apresentaram inibição das bactérias. Os resultados deste estudo sugerem que o óleo de copaíba autoclavado pode ser uma potencial fonte de novos agentes para o controle de infecção ou para a conservação dos alimentos, inibindo o crescimento de bactérias de origem alimentar como L. monocytogenes.

Palavras-chave: fitoterápicos, Copaifera, fármacos antimicrobianos, Listeria monocytogenes.

\section{INTRODUCTION}

Listeria monocytogenes, a food-borne pathogen, is the causative agent of listeriosis, a severe zoonotic disease that can lead to abortion, neurological disorders, sepsis and gastrointestinal disorders. It has been associated with foods such as raw milk, supposedly pasteurized milk, cheese, ice cream, raw vegetables, sausage meat, cooked and raw chicken,

ISetor de Medicina Veterinária Preventiva e Saúde Pública, Departamento de Veterinária, Universidade Federal de Viçosa (UFV), 36570-000, Viçosa, MG, Brasil. E-mail: masm@ufv.br. *Autor para correspondência. 
raw meat and raw or smoked fish. His ability to develop at temperatures as low as $3^{\circ} \mathrm{C}$, allows its multiplication in refrigerated foods (NORRUNG et al., 2009). Through FoodNet data (CDC, 1989), is estimated that 2493 cases of food-borne listeriosis occur each year, with 499 deaths, which makes $\mathbf{L}$. monocytogenes one of the five pathogens that cause more death in the U.S.A., accounting for $28 \%$ of deaths caused by diseases of dietary origin in that country (MEAD et al., 1999).

With the increase of bacterial resistance to antibiotics, there is considerable interest to investigate the antimicrobial effects of essential oils and different extracts against the bacteria range , to develop other classes of natural antimicrobials useful for the infection control or for food preservation (ALREZA et al., 2009).

The folk medicine has served as a source of compounds for use in the treatment of many diseases and combating several pathogens (PIERI et al., 2010; PIERI, et al., 2009). It has been highlighted, among the natural products in Brazil, the Copaiba (Copaifera sp.), that is a large tree that can reach up to 40 meters in height (ARAÚJO-JÚNIOR et al., 2005). Out of 72 species described worldwide by Index Kewensis, 16 are exclusive of Brazilian flora (HOOKER et al., 2009).

From the Copaiba tree is extracted an oil, called Copaiba oil, which has been used by more than 500 years in folk medicine with many potential properties for its use in medicine, as its healing properties like anti-inflammatory, antimicrobial and antiseptic action (PIERI et al., 2009).

This information obtained from folk medicine, indicating its use for many purposes, from most different kinds, for many years has been subject of several studies, to prove or adapt them to new therapies. In 1972, the Food and Drug Administration approved the Copaiba oil (FOOD AND DRUG ADMINISTRATION, 1972), after being subjected to tests for sensitization and irritation, using 25 volunteers, obtaining negative results for both (KLIGMAN, 1966).

Several studies have been conducted to identify microorganism's sensitivity to copaiba oils as antimicrobials, to their further use in drug therapies for diseases or in preventing them (PACHECO et al., 2006; PIERI et al., 2010; VALDEVITE et al., 2007). Grampositive bacteria have been constantly described as sensitive to this phytotherapic by researchers in this last years. The copaiba oil has many different substances that could act in different cell targets, acting synergistically in various structures and mechanisms of bacterial cell, resulting in a way to prevent or hinder the emergence of resistant bacteria (MENDONÇA \& ONOFRE, 2009; PACHECO et al. 2006; PACKER \& LUZ, 2007; PIERI et al., 2009; SANTOS et al., 2008).
The aim of this study was to evaluate the antimicrobial effect of different copaiba oil concentrations on the growth of $\boldsymbol{L}$. monocytogenes, and analyze differences in microorganism's inhibition with autoclaved and non autoclaved oil.

\section{MATERIAL AND METHODS}

\section{The Copaiba oil (Copaifera langsdorffii)} oil used here was exuded directly from the trunks of trees, according to PIERI et al. (2009). It was collected at Alfenas City, Minas Gerais State, Brazil, in September 2008 and the tree has the following geographic coordinates: $21^{\circ} 26^{\prime} 33^{\prime \prime S}$ and $46^{\circ} 0^{\prime} 55^{\prime \prime} \mathrm{W}$. After collecting, this material was maintained in amber bottle and stored at a temperature of $\pm 4^{\circ} \mathrm{C}$ for later analysis.

Three solutions were used. The solution used as negative control was prepared with $10 \mathrm{~mL}$ of tween 80 and $90 \mathrm{~mL}$ of distilled water and than autoclaved. The first test solution consisted of a solution with $80 \mathrm{~mL}$ destiled water and $10 \mathrm{~mL}$ of tween 80 autoclaved and added with $10 \mathrm{~mL}$ of copaiba oil non autoclaved. The second test solution was prepared with $10 \mathrm{~mL}$ of copaiba oil, $10 \mathrm{~mL}$ of tween 80 and $80 \mathrm{~mL}$ of destiled water, and autoclaved after.

A L. monocytogenes (ATCC 7644) strain and five other isolates of same bacterium specie (LM1, LM2, LM3, LM4 and LM5) were used for the tests, obtained from carcasses in a slaughterhouse.

Adapting the technique of diffusion in agar cylinder plating (ESMERINO et al., 2004) the bacteria was grown in Petri dishes containing a thin layer of bacteriological agar no1 (HIMEDIA, Mumbai, India), and another layer above of Tryptic soy agar (TSA) (OXOID, Hampshire, United Kingdom) supplemented with $0.6 \%$ yeast extract (OXOID, Hampshire, United Kingdom). Orifices were made only in TSA distributed on each plate, performing a center orifice and other six orifices marginally and harmoniously distributed. Each of these orifices, with $5 \mathrm{~mm}$ of diameter, was filled with one different concentration of test solutions serially diluted between $10 \%$ and $0.3125 \%$ of copaiba oil. The negative control solution was used into the center orifice of all plates.

The bacteria were inoculated on the TSA surface using a sterile swab, and each orifice was filled with its solution. Once prepared, the plates were incubated at $37^{\circ} \mathrm{C}$ for $24 \mathrm{~h}$. The antimicrobial activity was identified by the presence of any inhibition halo around the orifice. The inhibition halo was measured by the diameter length of inhibition halos to compare the activity concentrations. The tests were performed in triplicate. 


\section{RESULTS AND DISCUSSION}

Many natural oils had been tested and presented good results in $L$. monocytogenes inhibition as Cestrum nocturnum L. (ALREZA et al., 2009), Origanum vulgare (GUTIERREZ et al., 2009; MUÑOZ et al., 2009), Lonicera japonica Thunb (RAHMAN \& KANG, 2009), Thymus vulgaris, Melissa officinalis (GUTIERREZ et al., 2009) and Rosmarinus officinalis (MUÑOZ et al., 2009). These natural drugs can present many active principles acting in different structures in bacterial cells, hindering the emergence of resistant strains, then presenting a great advantage over conventional antimicrobial drugs.

The results of this research showed sensitivity of $\boldsymbol{L}$. monocytogenes strains related to the $10 \%$ autoclaved solution of copaiba oil, except the isolate LM3 which was resistant to all concentration of both copaiba oil solutions. The isolates LM1, LM2, LM4 and LM5 also showed sensitivity to the 5\% autoclaved solution. The LM4 also showed sensitivity to the $2.5 \%$ autoclaved solution. The $10 \%$ non autoclaved oil solution showed growth inhibition only for LM4 and LM5 isolates. This growth inhibition of $\boldsymbol{L}$. monocytogenes by a phytotherapic points some advantages over the emergence of resistant bacteria due to possible different action mechanisms performed by many active substances present in the oil, which could inhibit the bacterial resistance against the antimicrobial.

These results had pointed the $10 \%$ autoclaved solution of copaiba oil with higher inhibition as all other solutions and concentrations tested $(\mathrm{P}<0.05)$. For the other concentrations of both solutions, the five and $2.5 \%$ autoclaved and $10 \%$ non autoclaved solutions had presented statistically equal. No other concentration of both solutions and the negative control presented inhibition halo. Table 1 presents the mean of inhibition halos length for the solutions that present some activity against each $\boldsymbol{L}$. monocytogenes strains. The other concentrations did not show microbial inhibition, showing no inhibition halo, as well as the negative control. No article had described yet a comparison between autoclaved or non autoclaved copaiba oil different actions against any microorganism. It was supposed that the heat treatment could cause a change in the molecular structures that has given or potentiated the antimicrobial activity of the oil. This could explain the different results between the solutions.

Although there are no reports of antimicrobial testing of this oil against $\boldsymbol{L}$. monocytogenes, many studies have shown antimicrobial effect against several other bacterial species such as Staphylococcus epidermidis (SANTOS et al., 2008), S. aureus, Bacillus subtilis (PACHECO et al., 2006; SANTOS et al., 2008), Streptococcus mutans, S. pyogenes, S. salivarius, Enterococcus faecalis among others (PIERI et al., 2010; VALDEVITE et al., 2007).

Study has showed a synergistic effect, against Listeria species, with the combination of terpenic fractions of citrus oil and organic acids as malic acid and ascorbic acid (FRIEDLY et al., 2009). The copaiba oil, which is composed by a sesquiterpenic and terpenic fractions, may has a similar action in combination with organic acids. Thus some authors present a possible modification in the Listeria sensitivity to antimicrobial related to $\mathrm{pH}$ and other physicochemical alterations (NAÏTALI et al., 2009).

\section{CONCLUSION}

In conclusion, the results of this study suggest that the autoclaved copaiba oil may be a potential new agent source to the infection control or for food preservation, inhibiting the growth of foodborne bacteria such as $\mathbf{L}$. monocytogenes.

\section{ACKNOWLEDGMENTS}

The authors thank the Fundação de Amparo à Pesquisa de Minas Gerais (FAPEMIG) and Coordenação de Aperfeiçoamento de Pessoal de Nível Superior (CAPES).

Table 1 - Means of inhibition halos ( in mm) produced by different solutions of copaiba oil against six. L. monocytogenes strains (one ATCC an five slaugtherhouse isolates). Any other concentrations of these solutions present microbial inhibition. $\mathrm{R}$ is presented resitance of microorganism to the solution.

\begin{tabular}{|c|c|c|c|c|}
\hline Listeria monocytogenes & $\begin{array}{c}\text { Autoclaved solution } \\
10 \%\end{array}$ & $\begin{array}{c}\text { Autoclaved solution } \\
5 \%\end{array}$ & $\begin{array}{l}\text { Autoclaved solution } \\
\qquad 2,5 \%\end{array}$ & $\begin{array}{c}\text { Non autoclave solution } \\
10 \%\end{array}$ \\
\hline ATCC 7644 & $9 \mathrm{~mm}$ & $\mathrm{R}$ & $\mathrm{R}$ & $\mathrm{R}$ \\
\hline LM1 isolate & $12 \mathrm{~mm}$ & $10 \mathrm{~mm}$ & $\mathrm{R}$ & $\mathrm{R}$ \\
\hline LM2 isolate & $13 \mathrm{~mm}$ & $11 \mathrm{~mm}$ & $\mathrm{R}$ & $\mathrm{R}$ \\
\hline LM3 isolate & $\mathrm{R}$ & $\mathrm{R}$ & $\mathrm{R}$ & $\mathrm{R}$ \\
\hline LM4 isolate & $13 \mathrm{~mm}$ & $11 \mathrm{~mm}$ & $10 \mathrm{~mm}$ & $6 \mathrm{~mm}$ \\
\hline LM5 isolate & $11 \mathrm{~mm}$ & $11 \mathrm{~mm}$ & $10 \mathrm{~mm}$ & $8 \mathrm{~mm}$ \\
\hline
\end{tabular}




\section{REFERENCES}

ALREZA, S.M. et al. Chemical composition and inhibitory effect of essencial oil and organic extracts of Cestrum nocturnum $\mathbf{L}$. on food-borne pathogens. Int J Food Sci Technol, v.44, p.11761182, 2009. Available from: <http://www3.interscience.wiley.com/ cgi-bin/fulltext/122368424/HTMLSTART>. Accessed: Jun. 26, 2010 .

ARAÚJO-JÚNIOR, F.A. et al. Efeito do óleo de copaíba nas aminotransferases de ratos submetidos à isquemia e reperfusão hepática com e sem pré-condicionamento isquêmico. Acta Cir Bras, v.20, p.93-99, 2005. Available from: <http:// www.scielo.br/scielo.php?script $=$ sci_arttext \&pid=S0102$86502005000100013 \& \operatorname{lng}=$ en $\& n r m=$ iso \& $\ln g=p t>$. Accessed: Jan. 4, 2010.

CDC - CENTER FOR DISEASE CONTROL. Morbidity mortality weekly reports. Listeriosis associated with consumption of turkey franks. MMWR, v.38, p.267-268, 1989. Available from: <http://www.cdc.gov/mmwr/preview/index89.html>. Accessed: Jan. 4, 2010.

ESMERINO, L.A. et al. Método microbiológico para determinação da potência de antimicrobianos. Cienc Biol Saúde, v.10, p.5360, 2004. Available from: <http://www.revistas2.uepg.br/index.php/ biologica/article/viewFile/382/387>. Accessed: Jan. 4, 2009.

FOOD AND DRUG ADMINISTRATION. Food chemical codex. 2.ed. Washington, DC: U.S. Government Printing Office, 1972. 735p.

FRIEDLY, E.C. et al. In vitro antilisterial effects of citrus oil fractions in combination with organic acids. J Food Sci, v.74, p.67-72, 2009. Available from: <http://www3.interscience.wiley.com/cgi-bin/fulltext/ 121681485/HTMLSTART>. Accessed: Jan. 4, 2010

GUTIERREZ, J. et al. Antimicrobial activity of plant essencial oils using food model media: efficacy, synergistic potencial and interactions with food components. Food Microbiol, v.26, p.142-150, 2009. Available from: <http://www.sciencedirect.com/ science?_ob=ArticleURL\&_udi=B6WFP-4TTMNBB$1 \&$ us e r $=687369 \&$ c over Dat e $=04 / 30 /$ 2009\&_rdoc=1\&_fmt=high\&_orig=search\&_sort=d\&_docanchor $=$ \&view $=$ c\&_searchStrId $=1382673959 \&$ \&erunOrigin $=$ google \&_acct $=$ C000037901\&_version $=1$ \&_urlVersion $=0$ \&_userid $=687369 \& m d 5$ =4562ef930f14f2f35c7189e26b63a14f >. Accessed: Jan. 4, 2010.

HOOKER, J.D. et al. Index kewensis. Oxford, UK: Claredon, 2009. Supl. XX.

KLIGMAN, A.M. The identification of contact allergens by human assay. 3. The maximization: a procedure for screening and rating contact sensitizers. J Investig Dermatol, v.47, p.393-409, 1966.

MEAD, P.S. et al. Food-related illness and death in the United States. Emerg Infect Dis, v.5, p.607-625, 1999. Available from: <http://www.cdc.gov/ncidod/eid/vol5no5/mead.htm>. Accessed: Jan. 4, 2010.

MENDONÇA, D.E.; ONOFRE, S.B. Atividade antimicrobiana do óleoresina produzido pela copaiba - Copaifera multijuga Hayne (Leguminosae). Braz J Pharmacogn, v.19, p.577-581, 2009. Available from: <http://www.scielo.br/scielo.php?script=sci_arttext\&pid=S0102695X2009000400012\&lng=en\&nrm=iso\&tlng=pt $>$. Accessed: Jan. 4, 2010.
MUÑOZ, M. et al. Determination of the effect of plant essencial oils obtained by supercritical fluid extraction on the growth and viability of Listeria monocytogenes in broth and food systems using flow cytometry. Food Sci Tecnol (NY.), v.42, p.220-227, 2009. Available from: <http://www.sciencedirect.com/ science?_ob=ArticleURL\&_udi=B6WMV-4STYV5N-

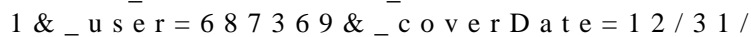
$2009 \&$ \&doc $=1 \&$ \& fmt $=$ high\&_orig $=$ search\&_sort $=$ d\&_docan chor $=$ \&view $=$ c\&_searchStrId $=1382679500 \&$ \&erunOrigin $=$ google \& _ a c c t $=000037901 \&$ _ version $=1 \&$ \&_url Versio $\overline{\mathrm{n}}=0$ \&_userid=687369\&md5=1d133a7c693cb88f3382cf90db7bc7a3>. Accessed: Jan. 4, 2010.

NAÏTALI, M. et al. Effects of $\mathrm{pH}$ and oil-in-water emulsions on growth and physicochemical cell surface properties of Listeria monocytogenes: impact on tolerance to the bactericidal activity of disinfectants. Int J Food Microbiol, v.130, p.101107, 2009. Available from: http://www.sciencedirect.com/ science?_ob=ArticleURL\&_udi=B6T7K-4VDY7V9$2 \&$ \& u s e r $=687369$ \&_c over D a t e $=03 / 31 /$ $2009 \&$ \& rdoc $=4 \&$ \& $\mathrm{mt}=$ high \&_orig=browse\&_srch $=$ doc info(\%23toc\%235061\%232009\%23998699997\%23941341\%23 FLA\%23display\%23Volume)\&_cdi $=5061 \&$ \&_sort=d\&_docanchor $=$ \&_ $\mathrm{ct}=13$ \&_acct $=\mathrm{C} 000037901$ \&_version $=1$ \&_urlVersion $=0$ \&_userid $=687369$ \& md5=9755b2e1db6d988b358c15c3127e0b23>. Accessed: Jan. 4, 2010 .

NORRUNG B. et al. Incidence and control of Listeria monocytogenes in foods in Denmark. Int J Food Microbiol, v.53, p.195-203, 1999. Available from: <http://www.sciencedirect.com/ science?_ob=ArticleURL\&_udi=B6T7K-3Y21GB5C \&_us e r =687369\&_cover Dat e $=12 / 15 /$ $1999 \&$ \&doc=18_fmt=high\&_orig=search\&_sort=d\&_docanchor $=\&$ view $=$ c\&_searchStrId $=1382681446 \&$ \&rerunOrigin $=$ go ogle\&_acct $=$ C000037901\&_version $=1 \&$ \&urlVersion=0\&_userid $=68$ 7369\&md5=3cb02b6e372a9f683b447c14dc84c628>. Accessed: Jan. 4, 2010.

PACHECO, T.A. et al. Antimicrobial activity of copaiba (Copaifera spp) balsams. Rev Bras Plantas Med, v.8, (n. esp.), p.123-124, 2006. Available from: <http:// www.ibb.unesp.br/servicos/publicacoes/rbpm/pdf_v8_esp/ 8esp_123_124.pdf >. Accessed: Jan. 4, 2010.

PACKER, J.F.; LUZ, M.M.S. Método para avaliação e pesquisa da atividade antimicrobiana de produtos de origem animal. Braz J Pharmacogn, v.17, p.102-107, 2007. Available from: <http:/ /www.scielo.br/pdf/rbfar/v17n1/a19v17n1.pdf>. Accessed: Jan. 4, 2010.

PIERI, F.A. et al. Efeitos clínicos e microbiológicos do óleo de copaíba (Copaifera officinalis) sobre bactérias formadoras de placa dental em cães. Arq Bras Med Vet Zootec, v. 62, 2010 .

PIERI, F.A. et al. Óleo de copaiba (Copaifera sp.): histórico, extração, aplicações industriais e propriedades medicinais. Rev Bras Plantas Med, v.11, p.465-472, 2009. Available from: <http://www.ibb.unesp.br/servicos/publicacoes/rbpm/ pdf_v11_n4_2009/art_16_465_472.pdf>. Accessed: Jan. 4, 2010 .

RAHMAN, A.; KANG, S.C. In vitro control of food-borne and food spoilage bacteria by essencial oil and ethanol extracts of Lonicela japonica Thunb. Food Chem, v.116, p.670-675, 2009. Available from: <http://www.sciencedirect.com/ 
science?_ob=ArticleURL\&_udi=B6T6R-4VT14M6B \&_u s e r $=687369 \&$ c ov e r D a t e $=10 / 01 /$ 2009\&_rdoc $=1 \&$ fmt=high\&_orig=search\&_sort=d\&_docanchor $=$ \& view $=$ c\&_searchStrId=1382685270\&_rerunOrigin=google\& acct $=\mathrm{C} 000037901 \&$ version $=1 \&$ urlVersion $=0 \&$ userid $=$ 687369\&md5=b736bc42e07e71e41534ce0eab28b83b $>$. Accessed: Jan. 4, 2010.

SANTOS, A.O. et al. Antimicrobial activity of Brazilian copaiba oils obtained from different species of the Copaifera genus. Mem Inst Oswaldo Cruz, v.103, p.277-281, 2008. Available from:
<http://www.scielo.br/scielo.php?script=sci_arttext\&pid=S007402762008005000015\&lng=en\&nrm=iso\&tlng=en >. Accessed: Jan. 4, 2010

VALDEVITE, L.M. et al. Study of the in vitro effect of copaíba oil upon virulence factors of the cariogenic bacterium Streptococcus mutans. In: IUBMB CONFERENCE, 10; REUNIÃO ANUAL DA SBBQ, 36., 2007, Salvador, BA. Anais... Salvador: Sociedade Brasileira de Bioquímica e Biologia Molecular, 2007. (CDRom). 